\title{
認知症外来患者に対する薬学的ヶアの有用性
}

\author{
佐藤雄已 ${ }^{* 1}$ ，吉岩あお 小 $^{2}$, 龍田涼佑 ${ }^{1}$ ，山本恭子 ${ }^{2}$, 宮嵪英士 ${ }^{2}$, 伊東弘樹 ${ }^{1}$ \\ 大分大学学医学部附属病院薬剤部 ${ }^{1}$, 大分大学医学部附属病院総合内科・総合診療科 ${ }^{2}$
}

\section{Usefulness of the Pharmaceutical Care for Treatment of Dementia Outpatients}

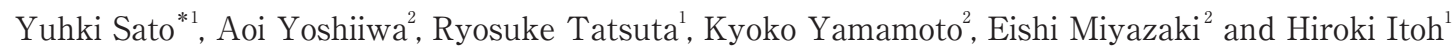 \\ Department of Hospital Pharmacy, Oita University Hospital ${ }^{1}$, \\ Department of General Medicine, Oita University Hospital ${ }^{2}$ \\ $\left[\begin{array}{l}\text { Received April 22, } 2016 \\ \text { Accepted September 26, } 2016\end{array}\right]$
}

The maintenance and improvement of medication compliance is important, and the medication counseling offered to dementia patients by pharmacists also plays an important role in providing effective dementia treatment. However, there have been no reports on pharmacists educating dementia patients continuously via an outpatient department to date. To achieve maintenance of taking medicine instruction and medicine compliance at Oita University hospital after August 2015 and in the outpatient memory care department of our hospital, where dementia patients undergo their medical examinations, a pharmacist delivered the new drug management instructions (hereafter, pharmacist outpatient department). Eighteen patients received instructions from a pharmacist from August 2015 through May 2016. We investigated the reasons why doctors requested these specific instructions, the intervention contents used by the pharmacist, and the outcome using a Mini-Mental State Examination (MMSE) before and after the instructions began and patients began the new medicine regimen. The results of the study found that the instructions by pharmacists increased their medicine use continuation rate, but MMSE had not changed. It is considered that the instructions given by pharmacists in dementia outpatient departments are connected to the maintenance of anti-dementia medicine regimens by improving patients' medicine-taking compliance.

Key words — dementia, cholinesterase inhibitor, pharmacist's outpatient clinic, compliance

\section{緒言}

日本において全人口における 65 歳以上の高齢 者の割合が 2 割を超え，超高齢化社会を迎えるな か, 認知症の増加が社会問題となっている. 最新 の厚生労働省の研究班による調査では，我が国に おける 65 歳以上の高齢者のうち認知症の割合は $15 \%$ と増加している. ${ }^{1)}$ 認知症治療の基本構造は, 薬物療法, 非薬物療法, 介護者の対応の工夫, リ ハビリテーションの 4 つのコンポーネントから成 り立っており，この 4 つのどれが欠けても治療は 成功しない. ${ }^{2}$ 認知症治療薬として, コリンエス
テラーゼ阻害薬（ChE-I）およびグルタミン酸受 容体拮抗薬が用いられ，これらを有効性と安全性 のバランスを考慮しながら使用していくことが, 認知症治療の鍵となる。さらに, 認知症治療薬の 有効性を維持するためには, 薬剤選択や使用方法 に注意することに加えて, 服薬コンプライアンス の向上が重要な課題とされている. 既報において, ドネペジル塩酸塩が開始となった患者の 1 年間の 服薬継続率について調査を行ったところ, 全体で $52.7 \%$ の患者が 1 年後には服薬できていないこと を報告している。 ${ }^{3)}$ その理由として，副作用によ る自己中断や薬効の理解不足などが挙げられてい

\footnotetext{
* $\mathbf{7} 879-5593$ 大分県由布市㣣間町医大ヶ 丘1-1
} 
る. 薬剂師が認知症患者に対して, 服薬指導のみ ならず家族教室や市民公開講座などの認知症に対 する心理教育や啓発活動などを実施し，多職種 チームに打ける活動の一翼を担っている。しかし ながら，現在までに外来において継続的に認知症 患者に薬剤師が指導を実施した報告は見当たらな い. 近年, 薬剤師による喘息患者への吸入指導, 外来化学療法実施患者への指導など，外来患者に 対する「薬剤師外来」の取り組みが多数報告され ている. ${ }^{46)}$ 大分大学医学部附属病院では 2015 年 8 月以降，認知症治療薬抒よび支持療法薬の服薬指 導，服薬コンプライアンスの維持・向上等を目的 とし, 認知症患者が受診する当院の物忘れ外来に

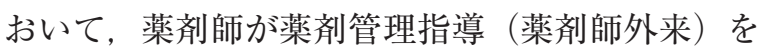
開始した。本研究では, 指導開始前後における, 対象患者の認知機能および服薬コンプライアンス を調查し, 薬剤師外来の有用性について検討した。

\section{方 法}

\section{1. 薬珮師外来の運用について}

当院，物忘れ外来（総合内科・総合診療科）の 診察日（水, 木曜日）の午後より, 外来診察室に て薬剂師が指導を行う。薬剤師外来の運用手順は 以下の通りである（図 1).

(1)医師の診察前の待ち時間を利用して，医師より 指導依頼された患者について認知機能・服薬コ ンプライアンス評価，副作用および残薬の確認 等を行い，指導内容を電子カルテに記載すると
ともに, 医師への連絡事項も記載する.

(2)医師診察後に, 医師より指導依頼された患者の 服薬コンプライアンス評価, 処方薬の説明・確 認を行い，指導内容を電子カルテに記載すると ともに, 必要に応じて, 医師へ電話にて連絡す る。また，院外薬局へ連絡事項がある場合は， 適宜お薬手帳に記載する。

\section{2. 調査対象}

2015 年 8〜11月の期間に指導を開始した患者 で, 2016 年 5 月までに, 3 回以上薬剂師外来にて 指導した認知症患者とした。なお調查期間は, 認 知症治療薬の国内外の臨床試験を参考に, 認知症 治療薬の効果判定を行える 6 力月間とした. ${ }^{7-9)}$ ま た, (1)認知機能検査未実施, (2)服薬継続確認不可 の患者を対象から除外した（図2）.

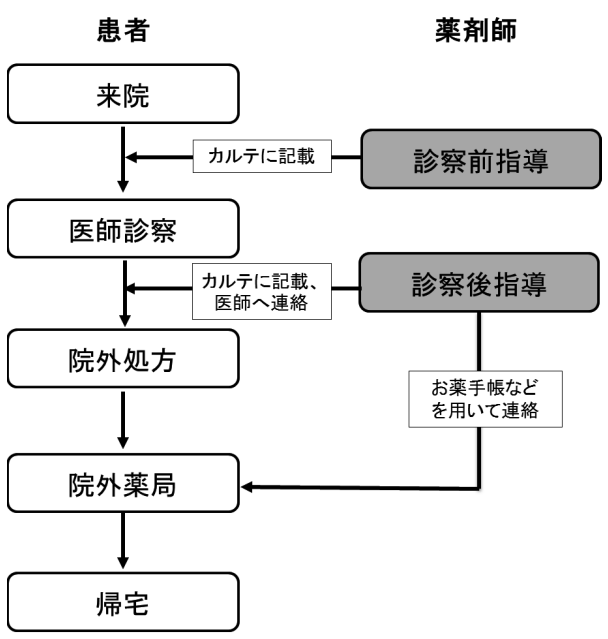

図 1 薬荗師外来における指導手順

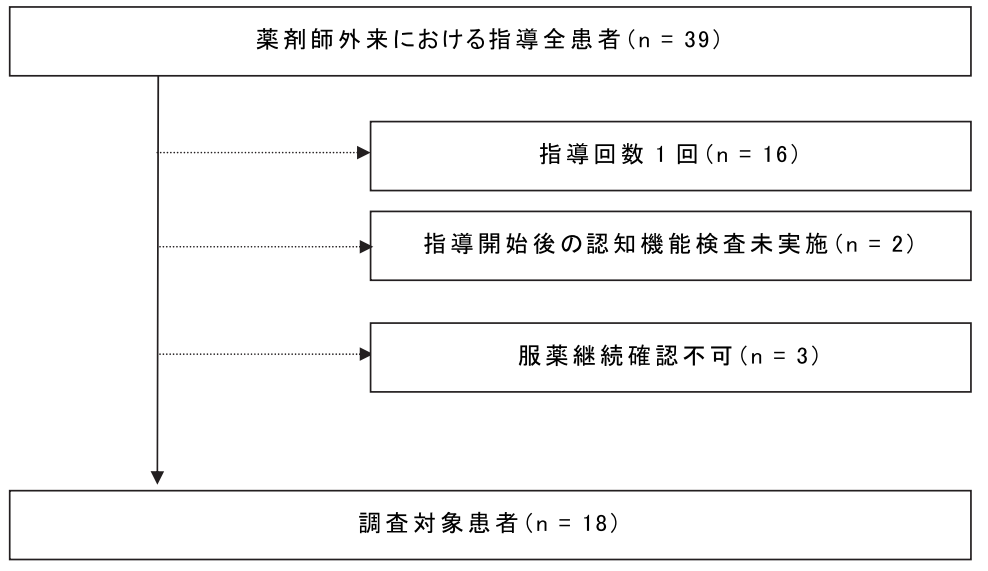

図 2 調査対象患者の選択フローチャート 


\section{3. 調查項目}

調查項目：(1)認知症治療薬の使用状況, (3)疾患 名, (4)患者背景 (年齢, 性別, 身長, 体重), (5)併 用薬について, 電子カルテより調査した. 臨床効果 の評価には，認知機能の評価スケールである minimental state examination（MMSE）を使用した. ${ }^{10)}$

\section{4. 医師からの指導依頼理由と, 指導内容および 転帰}

薬剤師が 3 回以上指導した薬剤師外来患者につ いて, 医師からの指導の依頼理由, 指導内容と, 指導後の転帰について調查した，なお，転帰が確 認できなかった患者は調査対象外とした。

\section{5. 認知機能の評価}

調查期間内に, 薬剂師が 3 回以上指導した薬剤 師外来患者を対象に，初回指導日および指導開始 後 6 カ月目にMMSE を実施後，スコアを算出し， 指導開始前後で比較した。

\section{6. 服薬継続の評価}

薬剂師が 3 回指導した薬剤師外来患者を対象 に, ChE-I 薬およびメマンチンの継続率を指導開 始前後で比較した。なお，評価期間は 6 力月とし た。また，服薬継続評価は，薬剤師外来受診時に 持参してもらった残薬を, 薬剤師と患者で確認す るピルカウント法で実施した。また，ChE-I 薬お よびメマンチンの実残薬数が予定残薬数の $100 \%$ の場合を「服薬コンプライアンス良好」, 100\%未 満の場合を「服薬コンプライアンス不良」と定義 した.

\section{7. 統計解析}

薬剤師外来開始前後における MMSE 值の差の 検定は Student's $t$-test（両側検定）により行った. 有意確率く0.05を有意差ありと判定した。

\section{8. 倫理規定}

本研究は「疫学研究に関する倫理指針」を遵守 し, 大分大学医学部倫理委員会の承認を得て実施 した（承認番号：946）。なお，本研究は「医療・ 介護関係事業者における個人情報の適切な取り扱
いのためのガイドライン」に留意して，実施し， 患者個人情報については匿名化して取り扱った。

\section{結 果}

\section{1. 患者背景}

対象期間に㧍ける指導対象患者数は 39 名で あった，そのうち，調查対象患者は 18 名であり， 全て指導開始以前より, 当院にて治療中であった (図 2). 対象患者の疾患内訳として，アルッハイ マー型認知症 ( $\mathrm{AD}$ ) が 15 名, レビー小体型認 知症（DLB）が 2 名, 軽度認知障害 (MCI) が 1 名であった。認知症治療薬である ChE-I として ドネペジルが最も多く使用され，次いで，リバス チグミン，ガランタミンの順であった。また，メ マンチンは単剂使用例が 1 名, 他剂との併用例が 10 名であった（表 1).

\section{2. 薬剤師外来患者における医師からの指導依頼 理由と，指導內容および転帰}

指導患者 18 名について, 指導依頼の理由とし ては，コンプライアンス不良が 13 名と最も多く， 次いで, 認知症治療薬変更に伴う服薬指導が 3 名, 併用薬の評価が 2 名であった（図 3)。指導患者 18 名それぞれの指導依頼の理由, 指導内容およ

表 1 調查対象患者背景

\begin{tabular}{|c|c|c|}
\hline \multicolumn{2}{|c|}{ 指導患者数 } & 18 名 \\
\hline \multicolumn{2}{|l|}{ 年齢* } & 72 歳（54-85） \\
\hline \multicolumn{2}{|c|}{ 性別（男性 / 女性） } & 14 名 / 4 名 \\
\hline \multicolumn{2}{|l|}{ 体重※※ } & $42.1 \pm 9.2 \mathrm{~kg}$ \\
\hline \multicolumn{3}{|l|}{ 主病名 } \\
\hline & 軽度認知障害 & 1 名 \\
\hline & アルツハイマー型認知症 & 15 名 \\
\hline & レビー小体型認知症 & 2 名 \\
\hline \multicolumn{3}{|c|}{ 認知症治療薬 } \\
\hline & ドネペジル & 8 名 \\
\hline & ガタンタミン & 2 名 \\
\hline & リバスチグミン & 7 名 \\
\hline & メマンチン & \\
\hline & 単剂 & 1 名 \\
\hline & 他剂併用 & 10 名 \\
\hline
\end{tabular}

※中央值 (範囲), ※※平均值 \pm 標準偏差

2015 年 8 月 1 日〜2016 年 4 月 30 日に指導を実施した患者計 39 名のうち, 指導回数 3 回以上の患者計 18 名 
び転帰について表 2 に示す。コンプライアンス 不良患者へは服薬指導を実施し, 残薬調整などを 実施した。また，副作用の理由等により，認知症 治療薬を自己中止した患者や多剤服用によりコン プライアンス不良であった患者へは，医師へ併用 薬の中止の提案および使用薬剤の整理を行った.

\section{3. 薬剤師外来前後における認知機能の変化}

指導患者 18 名の薬剤師による指導開始前後に

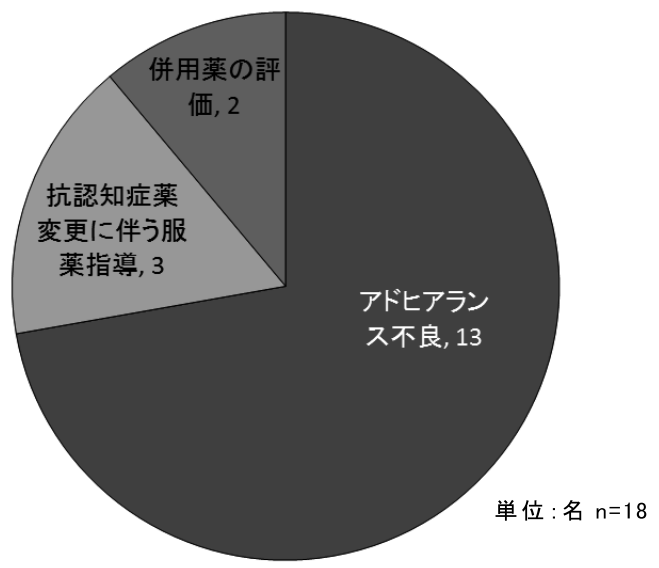

図 3 薬剂師外来患者に対する医師からの指 導依頼理由

3 回指導を実施した患者 18 名.
おける MMSE スコアの比較について図 4 に示す. 開始前後において, MMSEスコアの有意な変化 は認められなかった。

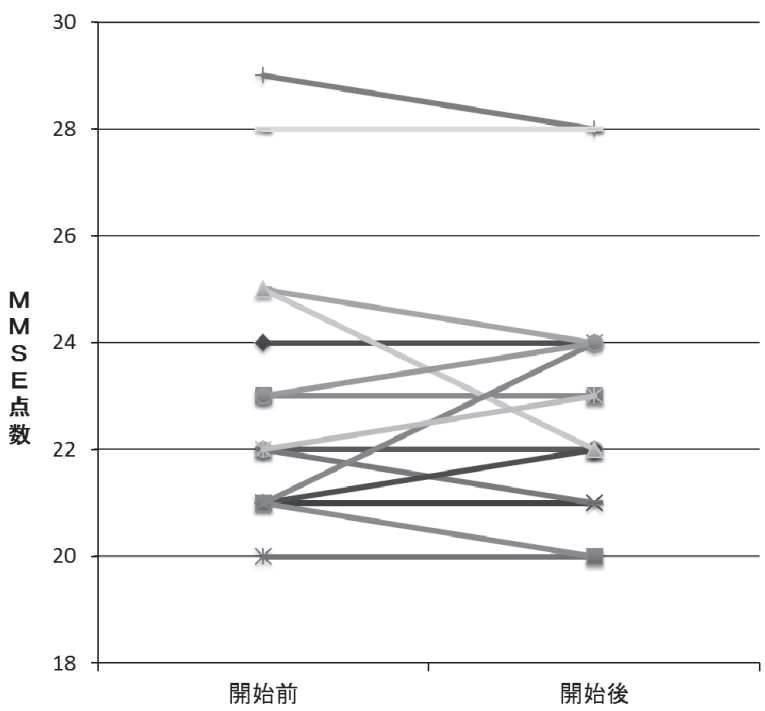

図 4 薬剤師外来患者における指導前後の認知機能 の比較

3 回指導を実施した患者 18 名. 数字は患者番号を示す

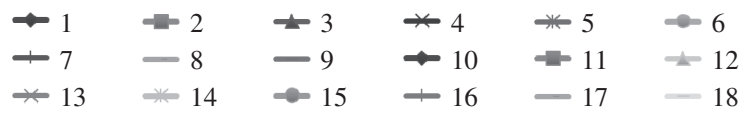

表 2 薬剤師外来における薬剤師の指導内容および転帰

\begin{tabular}{|c|c|c|}
\hline 患者 No. & 芥入理由 & 芥入内容と転帰 \\
\hline 1 & コンプライアンス不良 & 服薬指導実施. 服用忘れなく経過. \\
\hline 2 & コンプライアンス不良 & 服薬指導実施. 残薬調整後, お薬手帳に記載し, 保険薬局へ連絡. \\
\hline 3 & コンプライアンス不良 & めまい等により自己中止していたため, 医師へリバスチグミンの減量を依頼. \\
\hline 4 & コンプライアンス不良 & 服薬指導, 残薬調整 \\
\hline 5 & コンプライアンス不良 & 服薬指導, 残薬調整 \\
\hline 6 & コンプライアンス不良 & $\begin{array}{l}\text { フィジカルアセスメントにて頻脈の発現を確認. 医師へリバスチグミンを別の } \\
\text { 薬剤へ変更を提案 }\end{array}$ \\
\hline 7 & コンプライアンス不良 & 服薬指導実施. \\
\hline 8 & 抗認知症薬変更に伴う服薬指導 & 服薬指導. 副作用なく継続, コンプライアンス良好 \\
\hline 9 & 抗認知症薬変更に伴う服薬指導 & 服薬指導. 副作用なく継続，コンプライアンス良好 \\
\hline 10 & 抗認知症薬変更に伴う服薬指導 & 服薬指導. 副作用なく継続，コンプライアンス良好 \\
\hline 11 & 併用薬の評価 & 眠気強くアピリプラゾール中止を医師へ依頼 \\
\hline 12 & 併用薬の評価 & 頻尿があるため, フェソテロジンの追加を医師へ提案. 服用開始後, 頻尿改善. \\
\hline 13 & コンプライアンス不良 & $\begin{array}{l}\text { 服薬指導. 併用薬が多いことにより不安あり, } 20 \text { 年前より服用中のジフェニ } \\
\text { ドールについて現在症状がないため, 中止 }\end{array}$ \\
\hline 14 & コンプライアンス不良 & 服薬指導. お薬手帳に残薬を記載し, 保険薬局へ連絡. \\
\hline 15 & コンプライアンス不良 & 服薬指導, 残薬調整 \\
\hline 16 & コンプライアンス不良 & 服薬指導. ドネペジル服用後めまいあるため, 医師へ減量を提案し, 減量となった. \\
\hline 17 & コンプライアンス不良 & 服薬指導, 残薬調整 \\
\hline 18 & コンプライアンス不良 & 服薬指導, 残薬調整 \\
\hline
\end{tabular}




\section{4. 薬剤師外来開始前後における服薬コンプライ アンスの比較}

服薬コンプライアンス不良にて医師より指導依 頼があった患者 13 名について，薬凨師による指 導開始前, 開始後 3 力月および 6 力月における服 薬していない患者割合の推移を図 5 に示す。開 始前に比較し，開始後 3 力月（9/13名，69.2\%） および 6 カ月（3/13名, 23.1\%）で減少していた. なお，開始後 3 力月および 6 力月の追跡率は 100\%であった.

\section{考察}

薬剤師外来において, 薬剤管理指導の開始によ り，服薬継続率が向上した。また，今回，指導開 始前後で認知機能に変化は認められなかったが, 薬剤師の指導により，患者のコンプライアンスが向 上したことから，今後も継続して指導を続けること で，有効性の維持につながるものと考えられる.

認知症治療薬の長期投与が可能となってから, 初回投与後の漸増期間を超えると, 認知症治療薬 が長期処方されるケースが多い。また，薬郕師の 医師への提言によるドネペジル $10 \mathrm{mg} へ の$ 増量 は, 介護負担尺度にて評価した際に，4 週目以降， 介護者の負担を有意に軽減させたと報告されてい る. ${ }^{11)}$ そのため, 患者・家族を含めた薬剤管理指 導の重要性はますます高まるものと考えられる. 今回の取り組みにおいて, 長期的な認知機能や副

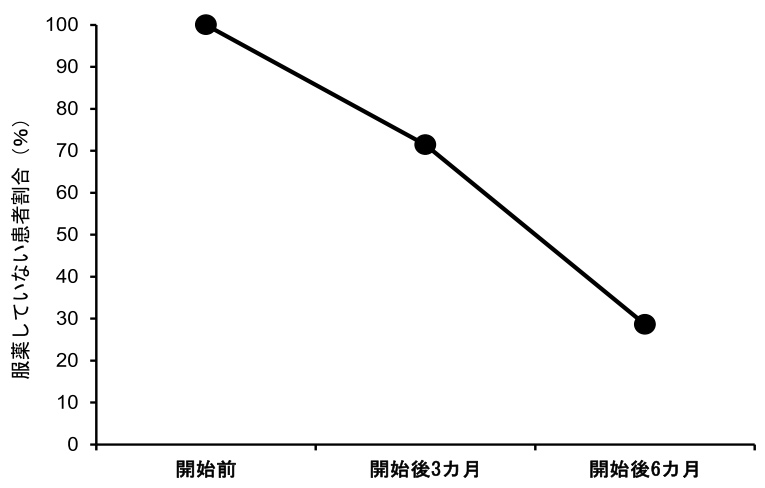

図 5 薬剤師外来患者における指導前後における服薬 コンプライアンス不良患者割合の比較

3 回指導を実施し, コンプライアンス不良患者 14 名. 縦軸は, 服薬していない患者の割合（\%）を示す。
作用の評価は実施できていなかった. しかしなが ら, 今回の取り組みにより, 服薬継続率が増加し, 外来において薬片師の必要性を裏付ける結果を示 すものと考えられる。すなわち，認知症患者に対 する薬物療法支援に招いて, 薬郕師がかかわるこ とで, 認知症患者に対する薬物療法の質向上につ ながるものと思われる.

本調査における服薬コンプライアンスの評価方 法としては, 外来受診時に, 残薬を持参してもら い, 残薬の数を確認するピルカウント法を採用し た。しかしながら，廃棄や持参忘れなどによる錠 数確認の不正確さが問題とされており, とりわけ, 医療者と患者との信頼関係が十分構築できていな い場合に問題になると報告されている。 今回, 服 薬継続率を調査した 18 名は, 全患者が通院歴 1 年以上と長く経過しているものの, 今後は, 自己 報告式評価と客観的な指標を組み合わせた多面的 評価法を実施するなど服薬コンプライアンスの評 価方法について検討が必要と考えられる。

認知症患者を対象とした薬剤師外来の有用性に ついては, Watanabe らが, 薬剤師外来実施群で は未実施群に比較し， 1 年間の服薬継続率は約 $25 \%$ 向上したと報告している. ${ }^{11)} こ の$ 報告では, 薬剂師による指導場所が, 薬剤部内であり, 主に, 医師の診断後のカウンセリングとなることが当院 の運用と異なる点である. さらに, 認知機能の評 価や医師への提案事項については検討されていな い. 今回の調査結果は, 薬剤師外来の有用性を認 知機能, 提案事項, 服薬コンプライアンスで評価 した点において, 薬剤師外来の有用性をより裏付 ける結果となった。また，介入症例は少ないもの の, 薬剤師外来に扔ける薬剤師の介入により, 副 作用を聴取し，医師へ ChE-I の減量や別薬剤への 変更を提案（表 2, 患者 No 6,16）, 拈よび併用薬 の中止や追加の提案（表 2, 患者 No 11,12）を行 えた点において, 薬片師の介入は意義深いものと 思われる.

本研究の限界として，アンケートなどを使用し た患者理解度の評価を実施していない点, 評価し た患者数が少ない点である，従って，今後は，患 者理解度と服薬継続率および認知機能との関連性 について検討していく必要がある. 


\section{利益相反}

開示すべき利益相反はない.

\section{引用文献}

1）厚生労働科学研究費補助金（認知症対策総合研 究事業）（研究代表者：朝田 隆）：総合研究報 告書「都市部における認知症有病率と認知症の 生活機能障害への対応」 2013.

2）新井平伊, 新規認知症治療薬に求められるも の; 認知症治療の新たな展開, 臨床精神薬理, 2011, 14, 1123-1129.

3) Umegaki H, Itoh A, Suzuki Y, Nabeshima T, Discontinuation of donepezil for the treatment of Alzheimer's disease in geriatric practice, Int Psychogeriatr, 2008, 20, 800-806.

4) Hasegawa M, Takagi K, Shimokata K, Byrd HJ, Nabeshima T, Evaluation of "Bronchial Asthma Pharmaceutical Care Clinic for Outpatients" Run by Pharmacists at Nagoya University Hospital, 医療薬 学, 2006, 32, 1038-1043.

5）今村牧夫, 名倉弘哲, 武本千恵, 外来がん患者に 対する薬剤師外来の有用性の検討, 医療薬学, 2010, 36, 85-98.

6）中島輝一, 真野泰成, 大内あかり, 佐藤大輔, 岩田 杏子, 樋口安耶, 江原邦明, 加藤芳徳, 廣澤伊織, 田島正教, 土屋文人, 山田治美, 小瀧 一, 旭
満里子, 外来がん患者に対する薬剤師外来の役 割とその評価, 医療薬学, 2012, 38, 599-608.

7) Folstein MF, Folstein SE, McHugh PR, "Minimental state" A practical method for grading the cognitive state of patients for the clinician, J Psychiatr Res, 1975, 12, 189-198.

8) Tariot PN, Farlow MR, Grossberg GT, Graham SM, McDonald S, Gergel I Memantine treatment in patients with moderate to severe Alzheimer disease already receiving donepezil: a randomized controlled trial, JAMA, 2004, 291, 317-324.

9) 本間 昭, 中村 祐, 斉藤隆行, 難波幸治, 石田 亮, ガランタミン臭化水素酸塩のアルツハイ マー型認知症に対するプラセボ対象二重盲検比 較試験, 老年精神医学雑誌, 2011, 22, 333-345.

10) Nakamura $Y$, Imai $Y$, Shigeta M, Graf A, Shirahase T, Kim H, Fujii A, Mori J, Homma A, A 24-week, randomized, double-blind, placebo-controlled study to evaluate the efficacy, safety and tolerability of the rivastigmine patch in Japanese patients with Alzheimer's disease, Dement Geriatr Cogn Dis Extra, 2011, 1, 163-179.

11) Watanabe N, Yamamura K, Suzuki Y, Umegaki H, Shigeno K, Matsushita R, Sai Y, Miyamoto KI, Yamada K, Pharmacist-based donepezil outpatient consultation service to improve medication persistence, Patient Preference and Adherence, 2012, 6, 605-611. 